\title{
Effects of habitat differences on the genetic diversity of Persicaria thunbergii
}

\author{
Bo Eun Nam ${ }^{1}$, Jong Min Nam ${ }^{1}$ and Jae Geun $\mathrm{Kim}^{1,2^{*}}$ (D)
}

\begin{abstract}
To understand the effects of habitat characteristics on the genetic diversity of Persicaria thunbergii, three sites of different environmental conditions in a water system were surveyed. Site A was the closest to the source of the water system, and there was a dam between sites A and B. Site C is located on the lowest downstream in the water system. Vegetation survey of four quadrats at each site was performed, and soil samples were collected for physicochemical analysis. Random amplification of polymorphic DNA (RAPD) analysis of ten $P$. thunbergii individuals at each site was conducted to calculate population genetic diversity and genetic distance among populations. Soil was sterile sand at site A, whereas loamy soil at sites B and C. A pure stand of $P$. thunbergii appeared at site A, while other species occurred together (such as Humulus japonicus and Phragmites australis) at sites B (ShannonWiener index; $\left.H_{B}=0.309\right)$ and $C\left(H_{C}=0.299\right)$. Similar to the species diversity, genetic diversity (Nei's gene diversity; $h$ ) within population of site $A\left(h_{A}=0.2381\right)$ was relatively lower than sites $B\left(h_{B}=0.2761\right)$ and $C\left(h_{C}=0.2618\right)$. However, site $C$ was separated from sites $A$ and $B$ in genetic distance rather than the geographical distance (Nei's genetic distance; $A \sim B, 0.0338 ; B \sim C, 0.0685 ; A \sim C, 0.0833)$.
\end{abstract}

Keywords: Cleistogamic flower, Genetic distance, Genetic diversity, RAPD-PCR

\section{Introduction}

Persicaria thunbergii (Siebold \& Zucc.) H. Gross is an annual Polygonaceae herb that commonly appears at diverse wetland ecosystems such as streamlets, abandoned paddy fields, montane fens, and floating mats in Korea (Kim 2009; Kim et al. 2012; Park et al. 2013). P. thunbergii inhabits widely and sometimes dominate in wetland ecosystems where the water level is not much deep (Kawano 2008; Kim et al. 2013). In Korea, $P$. thunbergii is occasionally considered as a management object due to its rapid recovery through asexual reproduction after harsh flooding disturbances (Kim et al. 2012).

P. thunbergii has the amphicarpic trait that produces different types of seeds only shown in a few species (Cheplick 1987). P. thunbergii produces not only aerial chasmogamous flower but subterranean cleistogamic flower (Kawano et al. 1990; Choo et al. 2014). Two types of seeds from different types of flower (aerial and subterranean seed) have significant differences in seed and seedling stage

\footnotetext{
* Correspondence: jaegkim@snu.ac.kr

'Department of Biology Education, Seoul National University, Seoul 08826,

South Korea

${ }^{2}$ Center for Education Research, Seoul National University, Seoul 08826, South Korea
}

properties (Choo et al. 2015). In addition, the ratio of aerial and subterranean flower and seed number varies under different hydrological conditions and soil fertility in $P$. thunbergii (Choo et al. 2014; Kim et al. 2016).

There might be differences in genetic diversity between two seed types in $P$. thunbergii as well as physiological differences in seed and seedling stage as a result of differences in flower type (aerial and subterranean). However, studies about the genetic diversity of the wetland plants mainly have focused on clonal, perennial species (Piquot et al. 1996; Koppitz 1999; Honnay et al. 2010; Min et al. 2012; Raabová et al. 2015). Previous studies on the genetic diversity of $P$. thunbergii only focused on their spatiotemporal genetic distribution (Konuma and Terauchi 2001; Kim et al. 2008). Genetic diversity of $P$. thunbergii could be affected by phenotypic plasticity in the ratio of aerial and subterranean flower production, as a result of the plasticity caused by their environment.

The aim of this study is to assess the genetic diversity of $P$. thunbergii populations with different environmental characteristics. Some ecological characteristics of $P$. thunbergii also would be considered in population genetic diversity. 


\section{Materials and methods}

\section{Study site}

The study was conducted at the Han River and Gyeongancheon stream which is a tributary to the Han River, Seoul and Gyeonggi Province, Republic of Korea. Field study was conducted in July 2014. Three sites where the coverage of P. thunbergii was more than 50\% with relatively few artificial disturbances were chosen for the field study and sampling (Fig. 1).

Site A (Yongin, Gyeonggi Province) is the upper region and adjacent to the source of Gyeongan-cheon $(<2 \mathrm{~km})$, where the width of the stream is $2 \sim 3 \mathrm{~m}$. Before Gyeongan-cheon joins the Han River at Paldangho Lake, in site B (Gwangju, Gyeonggi Province), P. thunbergii has been inhabited at the floodplain of stream which width is about $80-\mathrm{m}$ wide. Also, site C (Gangdong-gu, Seoul) is also a floodplain of the Han River with approximately 700-m width.

\section{Field survey and sampling of $P$. thunbergii}

Four $1 \mathrm{~m} \times 1 \mathrm{~m}$ quadrats were installed at each site. Vegetation survey was conducted at each quadrat. Relative coverage of emerged plant species and species diversity were calculated ( $H$; Shannon-Weiner index).

$$
\begin{aligned}
& \text { Relative coverage }=\text { cover of species } / \text { total cover } \\
& H^{\prime}=-\sum_{i=1}^{N} p_{i} \log p_{i}(N=\text { no. of emerged species; } \\
& \left.p_{i}=\text { relative coverage of species } i\right)
\end{aligned}
$$

Soil sampling was conducted closely by each quadrat. In case of site A, only one soil sample was collected because $P$. thunbergii population rooted on the rock with a little soil medium. For assessment on population genetic diversity of $P$. thunbergii, leaves of ten individuals in 2-minterval nearby quadrats were sampled at each site. Leaf samples were stored at $-20{ }^{\circ} \mathrm{C}$ until DNA extraction.

\section{Soil analysis}

Soil samples were passed through a $2-\mathrm{mm}$ sieve (standard sieve \#10) before analysis. Water content was determined after drying samples at $105^{\circ} \mathrm{C}$ in an oven, and analysis of organic matter content followed by the loss-on-ignition method at $550{ }^{\circ} \mathrm{C}$ furnace (Boyle 2004). Soil pH (AP63, Fisher, Hampton, USA) and conductivity (EC; Corning Checkmate II, Corning, Lowell, MA) were measured from the soil solution which is a mixture of soil samples with distilled water at a mass ratio of 1 to $5 . \mathrm{NO}_{3}-\mathrm{N}$ and $\mathrm{NH}_{4}-\mathrm{N}$ were extracted with $2 \mathrm{M} \mathrm{KCl}$ solutions and measured by a hydrazine method and indophenol method, respectively (Kamphake et al. 1967; Kim et al.

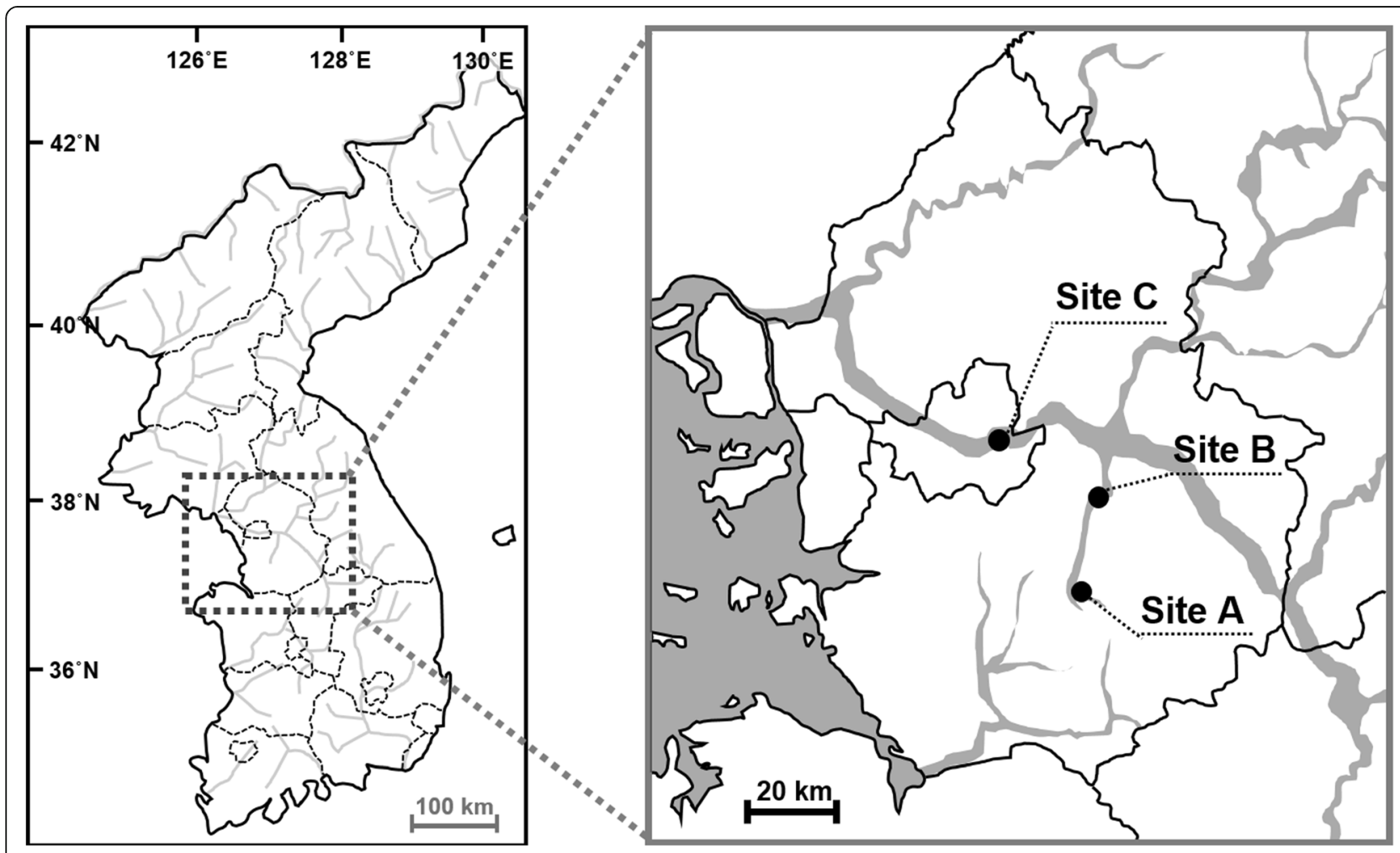

Fig. 1 Location of the study sites. Sites A and B are located at Gyeongan-cheon stream, and site C is located at the Han River 
2004). $\mathrm{PO}_{4}-\mathrm{P}$ was extracted and analyzed by a Bray No. 1 method (Bray and Kurtz 1945). Available $\mathrm{K}^{+}, \mathrm{Ca}^{2+}, \mathrm{Na}^{+}$, and $\mathrm{Mg}^{2+}$ were extracted with $1 \mathrm{~N}$ ammonium acetate solution (Allen et al. 1974) and measured with an atomic absorption spectrophotometer (AA240FS, Varian, Palo Alto, USA). Soil texture was determined using the hydrometer method and the soil texture triangle of USDA (Carter 1993).

\section{RAPD-PCR}

Extraction of individual genomic DNA was conducted by DNeasy Plant Mini Kit (Qiagen, Hilden, Germany). PCR was followed by using AccuPower PCR premix (Bioneer, Daejeon, Korea). The total reaction volume of PCR was $20 \mu \mathrm{L}$, composed of $1 \mu \mathrm{L}$ of extracted DNA, $1 \mu \mathrm{L}$ of primer $(10 \mathrm{pmol})$ and $18 \mu \mathrm{L}$ of deionized water. Four random primers which showed the polymorphism in electrophoresis were selected for random amplification of polymorphic DNA (RAPD) analysis (Table 1). Reaction cycle of PCR began with 2 min of denaturation at $94{ }^{\circ} \mathrm{C}$. Forty cycles were followed with $45 \mathrm{~s}$ of denaturation at $94{ }^{\circ} \mathrm{C}, 45 \mathrm{~s}$ of annealing at the $T_{\mathrm{m}}$ of each primer, and $1 \mathrm{~min}$ and $30 \mathrm{~s}$ of elongation at $72^{\circ} \mathrm{C}$. Lastly, $2 \mathrm{~min}$ of the final extension step at $72{ }^{\circ} \mathrm{C}$ was followed.

Electrophoresis of amplified fragments was conducted in GelRed $^{\mathrm{TM}}$ (BIotium, Heyward, CA) stained 1\% agarose gel. Under the UV light, bands were observed and recorded by binary character matrix with 1 (presence) and 0 (absence).

\section{Data analysis}

Genetic diversity within the population (number of polymorphic loci; Nei's gene diversity, $h$; Shannon index, $i$ ) and genetic distance (Nei's genetic distance) among populations were calculated by Popgen32 (Nei 1973; Yeh and Boyle 1997). Principal coordinate analysis (PCoA) with the presence and absence of each band was conducted by $\mathrm{R}$ version 3.1.1.

\section{Results}

Habitat characteristics of $P$. thunbergii populations

Relative coverage of $P$. thunbergii at sites A, B, and C were $100,52.5$, and $77.9 \%$, respectively. Five species emerged at site $C$, whereas three species emerged at site B (Table 2). At site A, only $P$. thunbergii emerged in the surveyed

Table 1 Random primer sequences and number of amplified RAPD fragments

\begin{tabular}{llll}
\hline Primer & Sequence & $T_{\mathrm{m}}\left({ }^{\circ} \mathrm{C}\right)$ & $\begin{array}{l}\text { No. of observed } \\
\text { bands }\end{array}$ \\
\hline $\mathrm{N}-8002$ & CAATCGCCGT & 32 & 13 \\
$\mathrm{~N}-8004$ & TCGGCGATAG & 32 & 7 \\
$\mathrm{~N}-8007$ & GTGACGTAGG & 32 & 9 \\
$\mathrm{~N}-8010$ & CTGAGACGGA & 32 & 11 \\
\hline
\end{tabular}

Table 2 Plant species, relative coverage (\%), and species diversity

\begin{tabular}{llll}
\hline & Site A & Site B & Site C \\
\hline Perennials & & & \\
$\quad$ Phragmites australis & - & - & 4.1 \\
$\quad$ Equisetum arvense & - & - & 0.9 \\
$\quad$ Artemisia princeps var. orientalis & - & - & 0.4 \\
Annuals & & & \\
$\quad$ Persicaria thunbergii & 100 & 52.5 & 77.9 \\
$\quad$ Humulus japonicas & - & 47.2 & 16.7 \\
$\quad$ Persicaria perfoliata & - & 0.3 & - \\
Shannon-Weiner index & - & 0.309 & 0.299 \\
\hline
\end{tabular}

quadrats although the other emergent macrophytes occurred nearby. Species diversity index (Shannon-Wiener index) at sites B and C were 0.309 and 0.299 , respectively.

At field survey, $P$. thunbergii population at sites B and $\mathrm{C}$ had a distance from the surface of the stream or river. However, the average water depth was $2 \mathrm{~cm}$ at site A. Soil characteristics at site $\mathrm{B}$ and site $\mathrm{C}$ were similar except $\mathrm{NH}_{4}-\mathrm{N}$ and $\mathrm{NO}_{3}-\mathrm{N}$ content (Table 3). Soil textures were sandy loam $\sim$ silt loam at site $B$, silt loam loam at site $C$, whereas there was sand at site A. EC (A, $37.2 \mu \mathrm{S} /$ $\mathrm{cm}$; B, 52.5 102.3 $\mu \mathrm{S} / \mathrm{cm}$; C, 61.8 92.6 $\mu \mathrm{S} / \mathrm{cm})$ and organic matter content (A. 2.25\%; B, 7.21 9.26\%; C, 7.54 9.23\%) at site A were considerably lower than sites $\mathrm{B}$ and C. Similarly, at site $\mathrm{A}, \mathrm{NO}_{3}-\mathrm{N}(\mathrm{A}, 0.53 \mathrm{mg} / \mathrm{kg} ; \mathrm{B}$, 2.01 3.51 $\mathrm{mg} / \mathrm{kg} ; \mathrm{C}, 4.57 \sim 5.35 \mathrm{mg} / \mathrm{kg})$ and $\mathrm{PO}_{4}-\mathrm{P}$ content (A, $6.75 \mathrm{mg} / \mathrm{kg} ; \mathrm{B}, 8.08 \sim 15.74 \mathrm{mg} / \mathrm{kg} ; \mathrm{C}$, $11.91 \sim 17.29 \mathrm{mg} / \mathrm{kg}$ ) were lower than sites B and C. However, $\mathrm{NH}_{4}-\mathrm{N}$ content at site $\mathrm{A}$ was relatively higher than sites $\mathrm{B}$ and $\mathrm{C}$ except one plot at site $\mathrm{B}$ (A, $12.5 \mathrm{mg} /$ $\mathrm{kg}$; B, 0.60 16.32 mg/kg; C, 0.49 1.63 mg/kg). $\mathrm{K}^{+}, \mathrm{Ca}^{2+}$, and $\mathrm{Mg}^{2+}$ content were relatively higher at sites $\mathrm{B}$ and $\mathrm{C}$

Table 3 Physicochemical soil characteristics (Mean \pm 1 SD)

\begin{tabular}{llll}
\hline & Site $\mathrm{A}(n=1)$ & Site B $(n=4)$ & Site C $(n=4)$ \\
\hline $\mathrm{pH}$ & 6.86 & $6.62( \pm 0.06)$ & $6.66( \pm 0.09)$ \\
$\mathrm{EC}(\mu \mathrm{S} / \mathrm{cm})$ & 37.2 & $75( \pm 20.9)$ & $79.2( \pm 12.8)$ \\
Water content $(\%)$ & 28.2 & $27.9( \pm 3.8)$ & $30.1( \pm 1.4)$ \\
$\mathrm{LOI}(\%)$ & 2.25 & $8.24( \pm 1.12)$ & $8.06( \pm 0.79)$ \\
$\mathrm{NH}_{4}-\mathrm{N}(\mathrm{mg} / \mathrm{kg})$ & 12.5 & $6.56( \pm 6.95)$ & $0.94( \pm 0.52)$ \\
$\mathrm{NO}_{3}-\mathrm{N}(\mathrm{mg} / \mathrm{kg})$ & 0.53 & $2.76( \pm 0.69)$ & $4.95( \pm 0.33)$ \\
$\mathrm{PO}_{4}-\mathrm{P}(\mathrm{mg} / \mathrm{kg})$ & 6.75 & $11.9( \pm 3.9)$ & $14.6( \pm 2.2)$ \\
$\mathrm{K}^{+}(\mathrm{mg} / \mathrm{kg})$ & 64.1 & $543.8( \pm 109.5)$ & $599.8( \pm 94.4)$ \\
$\mathrm{Na}^{+}(\mathrm{mg} / \mathrm{kg})$ & 19.9 & $18.1( \pm 1.4)$ & $16.8( \pm 1.7)$ \\
$\mathrm{Ca}^{2+}(\mathrm{mg} / \mathrm{kg})$ & 928.4 & $2467( \pm 240)$ & $2327( \pm 129)$ \\
$\mathrm{Mg}^{2+}(\mathrm{mg} / \mathrm{kg})$ & 94.4 & $272.8( \pm 37.8)$ & $322.1( \pm 40.6)$ \\
$\mathrm{Soil}^{2} \mathrm{exture}$ & Sand & Sandy loam & Loam or silt loam \\
\hline
\end{tabular}


than site $\mathrm{A}$, but $\mathrm{Na}^{+}$content was similar at the three sites (Table 3). Soil water content and $\mathrm{pH}$ showed just a little difference between sites $\mathrm{A}, \mathrm{B}$, and $\mathrm{C}$.

\section{Genetic diversity}

A total of 40 band loci were observed in four primers, and 35 of them were polymorphic. Each number of polymorphic loci at sites A, B, and C were 29, 28, and 29, respectively. The total Nei's gene diversity $(h)$ was 0.2969 and Shannon's information index $(i)$ was 0.4472 . The highest genetic diversity was observed at site B $(h=0.2761, i=0.4100$; Table 4$)$.

In a 2-D plot of PCoA based on 35 RAPD bands, individuals from three sites were mixed (Fig. 2). However, individuals from site $C$ were relatively separated from sites A and B on PCoA plot. Nei's genetic distance between sites $\mathrm{A}$ and $\mathrm{B}$ was 0.0338 , between sites $\mathrm{B}$ and $\mathrm{C}$ was 0.0685 , and between sites $A$ and $C$ was 0.0833 .

\section{Discussion}

The total potential genetic diversity of $P$. thunbergii population seemed to decrease when harsh flooding occurs in a natural habitat. In addition, high soil fertility increases the number of aerial seed production despite the decrease of mass allocation in aerial seeds (Kim et al. 2016). Considering the mass allocation, genetic diversity of $P$. thunbergii population is expected to be relatively higher in relatively fertile habitat than sterile habitat.

Both two sites with fertile soil are affected by annual harsh flooding in July and August (Han River Flood Control Office 2014). Although site A is located on the same water system as sites $B$ and $C$, the flooding pattern is different being closer to the source of the stream. The frequency of flooding disturbance seemed to be relatively higher, but the intensity seemed to be less harsh in site A than sites B and C. Weathering and sediment deposition by flowing water frequently occurred in sites B and C than site A, where soil is relatively sterile. Number of aerial seed production might be higher in sites $\mathrm{B}$ and $\mathrm{C}$, where the annual harsh flooding occurs with fertile soil (Choo et al. 2015; Kim et al. 2016). It also could contribute to the relatively higher genetic diversity than the habitat with oligotrophic soil.

While genetic diversity of sites $B$ and $C$ were similar, site $\mathrm{C}$ was genetically separated from sites $\mathrm{A}$ and $\mathrm{B}$. It

Table 4 Number of polymorphic loci and percentage, Nei's gene diversity $(h)$, and Shannon index (i) in the three sites

\begin{tabular}{llll}
\hline Site & No. of polymorphic loci (\%) & $h$ & $i$ \\
\hline Site A & $29(72.5)$ & 0.2381 & 0.3592 \\
Site B & $28(70.0)$ & 0.2761 & 0.4100 \\
Site C & $29(72.5)$ & 0.2618 & 0.3925 \\
Total & $35(87.5)$ & 0.2969 & 0.4472 \\
\hline
\end{tabular}

Total does not mean the sum of polymorphic loci numbers of three populations but the total loci number which considers overlapped loci among populations

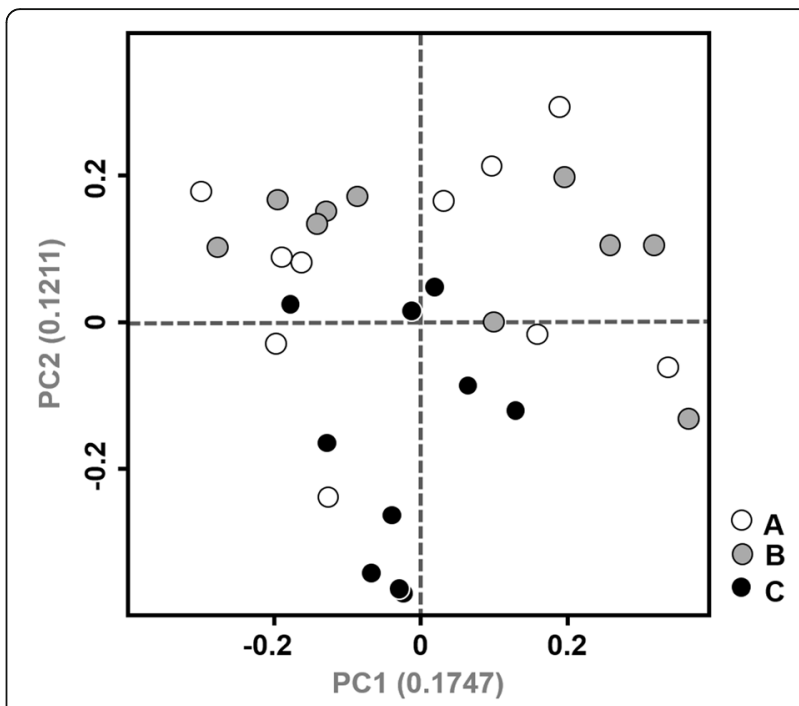

Fig. 2 2-D plot of principal coordinate analysis (PCoA) of $30 P$. thunbergii individuals with the presence and absence of 35 band loci. Values in parenthesis indicate the relative eigenvalue of each axis

could be inferred from the geographical barrier, a dam between two sites. In a previous study, $P$. thunbergii seemed to have a spatial genetic structure (isolation-bydistance) by reason of the limited seed dispersal (Konuma and Terauchi 2001). However, in this study, geographical barrier appeared to accelerate the genetic isolation between sites $B$ and $C$.

\section{Abbreviations}

PCR: Polymerase chain reaction; RAPD: Random amplification of polymorphic DNA; USDA: United States Department of Agriculture

\section{Acknowledgements}

Not applicable.

\section{Funding}

This study was supported by the Basic Science Research Program through the National Research Foundation of Korea (NRF-2012R1A1A2001007 and NRF-2015R1D1A1A01057373).

\section{Availability of data and materials}

The datasets during and/or analyzed during the current study are available from the corresponding author on reasonable request.

\section{Authors' contributions}

NBE participated in the design of the study, carried out the molecular studies, and wrote the manuscript draft. JGK conceived of the study, participated in the design of the study, edited the manuscript draft, and secured the funding. JMN participated in the field work. All authors read and approved the final manuscript.

\section{Competing interests}

The authors declare that they have no competing interests.

Consent for publication

Not applicable.

Ethics approval

Not applicable. 
Received: 23 August 2016 Accepted: 7 November 2016

Published online: 24 November 2016

\section{References}

Allen, S. E., Grimshaw, H. M., Parkinson, J. A., \& Quarmby, C. (1974). Chemical analysis of ecological materials. Oxford: Blackwell Scientific Publication.

Boyle, J. (2004). A comparison of two methods for estimating the organic matter content of sediments. Journal of Paleolimnology, 31, 125-127.

Bray, R. H., \& Kurtz, L. T. (1945). Determination of total, organic and extracted forms of phosphorus in soil. Soil Science, 59, 39-45.

Carter, M. R. (1993). Soil sampling and methods of analysis. Boca Raton: Lewis Publishers

Cheplick, G. P. (1987). The ecology of amphicarpic plants. Trends in Ecology \& Evolution, 2, 97-101.

Choo, Y. H., Kim, H. T., Nam, J. M., \& Kim, J. G. (2014). Flooding effects on seed production of the amphicarpic plant Persicaria thunbergii. Aquatic Botany, $119,15-19$.

Choo, Y. H., Nam, J. M., Kim, J. H., \& Kim, J. G. (2015). Advantages of amphicarpy of Persicaria thunbergii in the early life history. Aquatic Botany, 121, 33-38.

Han River Flood Control Office. (2014). Annual report on hydrology in Republic of Korea-water level. http://hrfco.go.kr/web/sumun/floodgate.do Accessed 16 Nov 2016.

Honnay, O., Jacquemyn, H., Nackaerts, K., Breyne, P., \& Looy, K. V. (2010). Patterns of population genetic diversity in riparian and aquatic plant species along rivers. Journal of Biogeography, 37, 1730-1739.

Kamphake, L. J., Hannah, S. A., \& Cohen, J. M. (1967). Automated analysis for nitrate by hydrazine reduction. Water Research, 1, 205-216.

Kawano, S. (2008). 11: Polygonum thunbergii Sieb. Et Zucc. (Polygonaceae). Plant Species Biology, 23, 222-227.

Kawano, S., Hara, T., Hiratsuka, A., Matsuo, K., \& Hirota, I. (1990). Reproductive biology of an amphicarpic annual Polygonum thunbergii (Polygonaceae): spatiotemporal changes in growth, structure and reproductive components of a population over an environmental gradient. Plant Species Biology, 5, 97-120.

Kim, J. G. (2009). Ecological characters of Sphagnum fens in Mt. Odae: I. Sowhangbyungsan-neup. Journal of Korean Wetland Society, 11, 15-27.

Kim, J. G., Park, J. H., Choi, B. J., Shim, J. H., Kwon, G. J., Lee, B. A., Lee, Y. W., \& Ju, E. J. (2004). Methods in ecology. Seoul: Bomoondang.

Kim, Y. H., Tae, K. H., \& Kim, J. H. (2008). Genetic variations and relationships of Persicaria thunbergii (Sieb. \& Zucc.) H. Gross ex Nakai (Polygonaceae) by the RAPD analysis. Korean Journal of Plant Resources, 21, 66-72.

Kim, D. H., Choi, H., \& Kim, J. G. (2012). Occupational strategy of Persicaria thunbergii in riparian area: rapid recovery after harsh flooding disturbance. Journal of Plant Biology, 55, 226-232.

Kim, D. H., Kim, H. T., \& Kim, J. G. (2013). Effects of water level and soil type on the survival and growth of Persicaria thunbergii during early growth stages. Ecological Engineering, 61, 90-93.

Kim, J. H., Nam, J. M., \& Kim, J. G. (2016). Effects of nutrient availability on the amphicarpic traits of Persicaria thunbergii. Aquatic Botany, 131, 45-50.

Konuma, A., \& Terauchi, R. (2001). Population genetic structure of the selfcompatible annual herb; Polygonum thunbergii (Polygonaceae) detected by multilocus DNA fingerprinting. American Midland Naturalist, 146, 122-127.

Koppitz, H. (1999). Analysis of genetic diversity among selected populations of Phragmites australis world-wide. Aquatic Botany, 64, 209-221.

Min, S. J., Kim, H. T., \& Kim, J. G. (2012). Assessment of genetic diversity of Typha angustifolia in the development of cattail stands. Journal of Ecology and Field Biology, 35, 27-34.

Nei, M. (1973). Analysis of gene diversity in subdivided populations. Proceedings of the National Academy of Sciences of the United States of America, 70, 3321-3323.

Park, J., Hong, M. G. \& Kim, J. G. (2013). Relationship between early development of plant community and environmental conditions in abandoned paddy terraces at mountainous valleys in Korea. Journal of Ecology and Environment, 36, 131-140.

Piquot, Y., Saumitou-Laprade, P., Vernet, P. P., \& Epplen, J. T. (1996). Genotypic diversity revealed by allozymes and oligonucleotide DNA fingerprinting in French populations of the aquatic macrophyte Sparganium erectum. Molecular Ecology, 5, 251-258

Raabová, J., Rossum, F. V., Jacquemart, A., \& Raspé, O. (2015). Population size affects genetic diversity and fine-scale spatial genetic structure in the clonal distylous herb Menyanthes trifoliata. Perspectives in Plant Ecology, Evolution and Systematics, 17, 193-200.

Yeh, F. C., \& Boyle, T. J. B. (1997). Population genetic analysis of codominant and dominant markers and quantitative traits. Belgian Journal of Botany, 129, 157.

\section{Submit your next manuscript to BioMed Central and we will help you at every step:}

- We accept pre-submission inquiries

- Our selector tool helps you to find the most relevant journal

- We provide round the clock customer support

- Convenient online submission

- Thorough peer review

- Inclusion in PubMed and all major indexing services

- Maximum visibility for your research

Submit your manuscript at www.biomedcentral.com/submit 